(JLSTS-1994-Sep.)

Vol.6 No.3

\title{
補助動力付き手動車いす
}

垣 本 映* 舟久保 昭 夫* 鈴 木 重 信* 関 口 行 雄*

\section{Development of Wheelchair with Assistive Power Unit}

Akira KAKIMOTO*, Akio FUNAKUBO*, Shigenobu SUZUKI*, Yukio SEKIGUCHI*

*Department of Rehabilitation Engineering, The Polytechnic University

\begin{abstract}
A wheelchair with an assistive power unit employing a differential gear is now under development. The wheelchair is specially aimed to those who have a little residual power to drive a hand driven wheelchair, but often use a powered wheelchair. People who have C5 or C6 level spinal cord injury or the aged who have lower limb impairment are initially considered. The purpose is to encourage them to keep their residual ability or even to improve it by adjusting the assistive power.

A prototype has been developed and tested on experimental basis. The prototype has one DC servo motor $(120 \mathrm{~W})$ and the output torque is transmitted to rear wheels through a differential gear, Oldam's shaft couplings and electromagnetic clutches. Applying voltage to the clutches turns the land-driven wheelchair into a powered wheelchair. The control system is utilizing an 8 bit single chip microcomputer and rotation angle sensors. Velocity feedback control is installed in the software.

In addition to performance tests following the JIS test procedures, 11 subjects, hand-driven wheelchair users tried the prototype and found its operation easy and that it is helpful when ascending or descending a slope.
\end{abstract}

Key Words

Wheelchair, Powered wheelchair, Assistive Power, Differential gear, Microcomputer Control

\section{1.はじめに}

平成 3 年度の厚生省の調査によれば，肢体不 自由障害者の総数は約 155 万人であった1)。ある 車いすメーカーによると，このうち車いすを利 用する障害者は約 25 万人で，リハビリテーショ ンや下肢機能の低下のため使用する人の約 25 万 人と合わせると計約 50 万人が車いすを使用して

* 正会員 職業能力開発大学校 福祉工学科 干229 神奈川県相模原市橋本台4-1-1
いるそうである。今後，我国の急速な高齿化を 考えるとその数は急激に增加すると考えられる。 移動支援機器としての車いすに対する個々の多 様なニーズも高まってくるであろう。

現在の車いすは大きく，手動車いすと電動車 いすに分けられる。手動車いすは軽量で折り盢 みができるものもあり運搬が容易である。一方， 電動車いすは下肢だけでなく上肢の不自由な人 にとって移動を確保する上できわめて有効な機 器である。しかしながら, 人も含めて重量が100 
$\mathrm{kg}$ を越え，階段や段差などで介助する場合たい へん重く，普通乗用車への搭載も困難である。 また電動車いすを使用する場合、わずかな操作 力で使用できる反面、現在保有している上肢の 残存機能さえも低下させてしまうことが眯念さ れる。さらに，段差やスローブなどを移動する 際に補助を必要とするという人に関して，市販 の電動車いすほどの駆動力を必要としない場合 が多いと考えられる。

また，手動車いすを利用していた障害者が， 加秢にともなって上肢機能が低下し，使用する 場所によっては補助的な動力が必要となってき ている。ここで手動車いすから電動車いすに乗 り換えてしまうことは、本人にとって保有機能 の低下をもたらすといった肉体的な問題ばかり でなく、自信を失うといった精神的な問題をも 生じ得る。これは筋ジストロフィーなど進行性 疾患の患者にもあてはまる5)。

これらを背景として，介護用を兼用するもの も含め，補助輪 1 輪の補助動力装置や前輪や後 輪を生かした 2 輪型の補助動力装置が開発，商 品化されてきている。しかしながら，旋回性能 の面で回転半径が小さくとれなかったり，手動 による操作と補助による操作の切り替えが容易 でないなどの難点があった。

これを踏まえ，我々は手動車いすに補助動力 装置をつけた自操式の補助動力付き手動車いす を試作した。本研究ではその構成, 仕様, 機構, 駆動方法，また工学的評価，車いす利用者によ る評価の方法とその結果につき報告する。

\section{2.対象者と使用環境，使用方法}

補助動力付きの車いすを設計する際に，対象 とする人とその使用環境，並びに使用方法を明 確化する必要がある。本研究では対象者として, 屋内などの平坦な床面で自操式の車いすをわず かでも操作することができるだけの保有能力を 持っている人，すなわち脊髄損傷レベルでC 5 ， C 6 レベルかそれよりも下肢運動機能障害が軽 度な人，またそれに準ずる人（高粭者など）と した。

使用環境に関しては，スロープ，段差など補
助が必要とされることが多い屋外での使用を主 に対象とした。

使用方法については, 補助の必要をトルクセ ンサ，速度センサなどで検知し，介助を自動化 する制御方法も考えられるが，ここでは使用者 の判断で補助の有無を決め，スイッチにより， 走行速度を設定し，その補助量を変えることに した ${ }^{7 / 8)}$ 。

\section{3. 構 成}

\section{1 仕 様}

2 までに述べた背景を踏まえ，補助動力付き 車いすを試作するにあたり次の要件を検討した。 (1)小型軽量であること。

(2)補助動力による動作と手動動作が簡単に切り 替えられること。

(3)補助動力量が使用者の車いす駆動特性に合わ せて変えられること。

(4)低価格に抑えられること。

この結果, 以下の点を設計仕様として決定し た。

(1)駆動源としてDCモータを1つだけ使用するこ と。

(2)差動歯車機構を使用し軸直結型で後輪 2 つを 駆動すること。

(3)電動クラッチを用いて手動, 補助の切り替え を行うこと。

(4)駆動電圧等を変えて補助動力量を調節できる こと。

(5)市販の車いすを基台とすること。

(6)操舵は使用者が行うこと。

以上により試作した車いすの構成を図 1 に示す。 主な仕様を表 1 に示す。

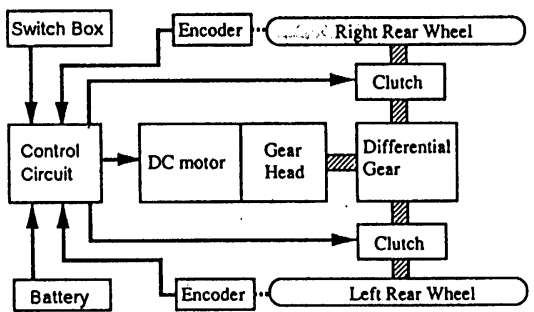

Fig.1 Configuration of wheelchair with assitive power unit 
Table.1 Specifications of wheelchair with assistive power unit

\begin{tabular}{|c|c|}
\hline Actuator & $\begin{array}{l}\text { Gear-headed DC motor } \\
24 \mathrm{~V} 120 \mathrm{~W}\end{array}$ \\
\hline Differential gear & $\begin{array}{l}\text { Gear ratio } 5: 2 \\
\text { Module } 1.0(\mathrm{~mm})\end{array}$ \\
\hline Clutch & $\begin{array}{l}\text { Electromagnetic } \\
\text { off : hand-driven } \\
\text { on : power assist }\end{array}$ \\
\hline Physical dimensions & $\begin{array}{lr}\text { Length : } & 1100(\mathrm{~mm}) \\
\text { Height : } & 880 \\
\text { Width : } & 630 \\
\text { Seat .width : } & 400\end{array}$ \\
\hline Battery & $6 \mathrm{~V} \times 2,12 \mathrm{~V} \times 1$ \\
\hline Weight & $36.5 \mathrm{~kg}$ \\
\hline
\end{tabular}

\section{2 機構と要素}

本研究でフレームとして使用した車いすは駆 動軸の取付が容易な片麻㿎者用のものである。

一般的な車いすではフレームのパイプから突 き出た片持ち軸に，車輪が八ブを介して滑り対 偶をなす構造となっている。これに対して片麻 盘者用のものは, 健側から患側の後輪を軸を介 して駆動する構造となっているため，軸を取り 付けるためのべアリングが溶接で固定されてお ク，追加工が少なくて済むのでコストが抑えら れる。

動力はDCモータからオルダム継ぎ手を介して 減速比 $5 ： 2$, モジュール $1, \mathrm{~S} 45 \mathrm{C}$ 製の差動 歯車機構に伝えられる。さらにこの出力が左右 の駆動軸にオルダム継ぎ手を介してそれぞれ伝 達され, 電動クラッチを経て左右の駆動輪に伝 達可能である。クラッチが励磁されると軸が接 続され,駆動トルクが伝達される仕組みである。

補助動力の駆動源として使用するモー夕の選 択に関しては文献 ${ }^{2)} よ り 日$ 常生活で必要な駆動 力が約 $30 \mathrm{~N} \cdot \mathrm{m}$ であること, 傾斜 12 分の 1 , 路面 抵抗0.015のスロープ（建築基準の推奖值）を75 $\mathrm{kg}$ の人が車いす $35 \mathrm{~kg}$ （基礎の車いす $20 \mathrm{~kg}$, 補助 機構 $15 \mathrm{~kg}$ とした）に乗って, 毎秒 $1 \mathrm{~m}$ の速度 (人がゆっくり歩く速度) で移動できるとする 時の計算上の必要出力 $132 \mathrm{~W}$ 根拠として, 定格
出力 $120 \mathrm{~W}$ (最大 $240 \mathrm{~W}$ ), 定格卜ルク約 $20 \mathrm{~N} \cdot \mathrm{m}$ (最大約 $120 \mathrm{~N} \cdot \mathrm{m}$ 以上)のギヤヘッド付き $24 \mathrm{VDC}$ モータを使用することにした。

電動クラッチに関しては小型で伝達トルクの 高い $24 \mathrm{~V}$ 動作のッースクラッチを使用すること にした。最大伝達トルクは片側で約 $25 \mathrm{~N} ・ \mathrm{~m}$ あ。 バッテリーは重量効率が優れた小型軽量のシ ールド電池を使用し，モータの定格電流で使用 した場合に，30分以上連続使用可能な容量とし て12V7Ah(6Vは6Ah)のものを用いた。

駆動機構をフレームに取り付けるにあたって 剛性を上げ，確実に動力が伝達されるよう今回 は脱着化を考虑しないことにした。板金加工し た板厚 $2 \mathrm{~mm}$ のアルミニウムをフレームに固定し, その上に駆動機構を取り付けている。

試作した補助動力機構を取り付けた車いすの 平面図と左側面図を図 2 に示す。駆動機構は座 面の下にすっぽりと納まっている。

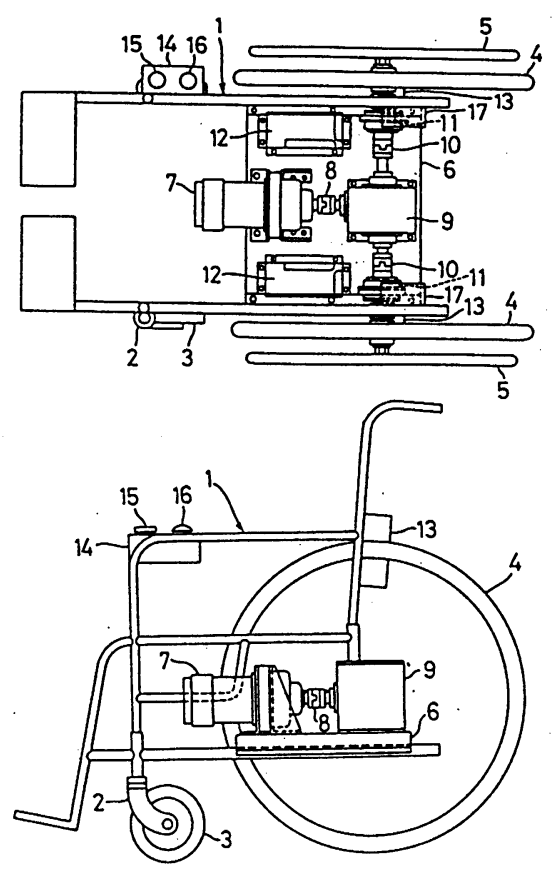

Fig. 2 Top view and left side view

1. Frame 2.Bracket 3.Caster 4.Rear wheel 5.Pushrim 6.Base 7.DC motor 8.10.01dam's shaft coupling 9.Differential gear 11. Ball bearing 12 .Sealed battery 13. Control circuit 14. Switch box 15. Button for speed set 16. Button for stop 
全重量はバッテリーと制御装置を含めて 36.5 $\mathrm{kg}$ となり市販の電動車いすのおよそ半分である。

\section{3 制御装置}

補助動力装置の仕様で述べたように, 本研究 で目標にしている車いすは，仕様者の駆動特性 に合わせて補助動力量を加減するということで ある。このためには，車いすを使用している人 がどのくらいの駆動力を車いすに作用させてい るかを知る必要がある。すなわち，トルクセン サが必要になってくる。しかし，トルクセンサ の選択，取付法，信号伝送法など解決しなけれ ばならない課題が多い。

本報告では，滑らかな加減速を行うこと，負 荷変動による速度変化を抑えることにより，乗 り心地を良くするため，速度フィードバック制 御を実現することにした。

当初，機構，動力の動作を確認するなどの基 礎実験を行うため, 補助動力量を 3 段階設定で きるよう, リレーによるモー夕駆動電圧切り替 之回路 $(12 ， 18 ， 24 \mathrm{~V})$ を製作した。しかしな がら，電圧による駆動電圧設定だけでは負荷変 動を生じたときに走行速度も変化してしまう。 スロープを上り切った時など，急に加速して危 険である。また起動時や停止時には加減速なし では慣性のための衝撃が大きく，機械系統にダ メージを与える可能性がある。そこでワンチッ プマイクロコンピュータを用いた制御回路を作 成し，連続的な速度制御が行えるようにした。 図 3 に制御回路のブロック図を示す。

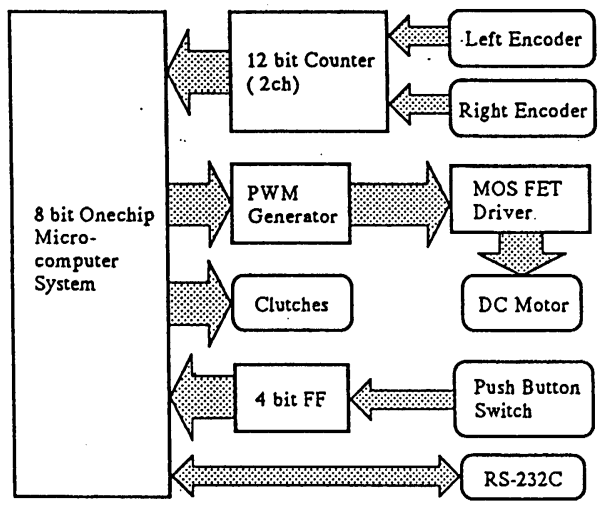

Fig. 3 Blockdiagram of control system
制御回路は使用者からの補助動力のオンオフ や速度の設定を取り込むスイッチボックス，ワ ンチップマイクロコンピュータ回路，モータ駆 動PWM信号発生回路，回転角度センサの信号 を処理するカウンタ回路，パワーMOSFETを 用いたモータ，ブレーキ駆動回路，シリアル通 信回路からなる。シリアル通信回路は，車いす 駆動時の駆動データのホストコンピュータへの アップロード，ホストから開発したプログラム のダウンロードなどに用いる。

センサとして，負荷変動時に速度をフィード バックするため, 回転方向のわかる回転角度七 ンサ（図 3 のEncoder）を考案した。回転角度 センサーは図 4 のように小型リードスイッチを 2 つ平行にならべて背もたれ部と座面の交点に あたる位置に左右 1 対ずつ設置し，後輪のスポ 一クに取り付けたマグネットが接近する度に， 位相の異なるパルスを出力するようにしたもの である。この 2 つの信号の立ち上がりと立ち下 がりにおける片方のスイッチの動作状態を見る ことにより，回転角度のみでなく回転方向も認 識することが可能となる。120度おきにマグネッ 卜を配置し 3 分の 1 の回転角度（移動量にして $60 \mathrm{~cm})$ の分解能がある。マイクロコンピュータ 内の夕イマと組み合わせることにより速度を求 めることができる。

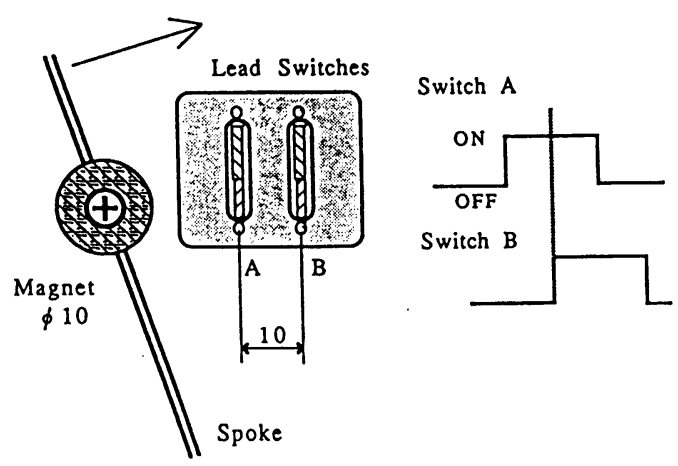

Fig.4 Rotation angle sensor with two micro lead switches

\section{4 速度制御の方法(ソフトウエア)}

使用者の体重の違いによる重量の変化や，ア ップダウンなど路面の状態の变化により，モー 夕に対する負荷が変動しても，速度が大きく変 
動することのないように速度フィードバック制 御を行う。

このため, PWM波形のデューティ比を等価 な駆動電圧に換算して，PID制御することも考 えられるが，ここでは予め，負荷を変え，定常 時のデューティ比と回転速度の関係を求め, こ れをテーブル化した。負荷を推定し，その都度 テーブルを参照することにより目標速度を維持 できるようプログラムを作成した。

具体的には正の負荷（上り）を想定し，車い

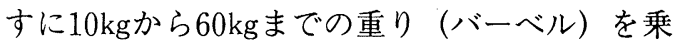
せ，角度 12 分の 1 のスロープをデューティ比を 変えて上らせ，速度をテーブル化した。また負 の負荷（下り）としてはブレーキのデューティ 比を変えてスロープを下らせ, 速度をテーブル 化した。負の負荷の有無は, 速度の変化, すな わち加速度を求め, 実験的な值を指標として判 断する。

\section{4. 実験}

\section{1 性能試験}

JIS電動車いす ${ }^{3)}$ ，またJIS手動車いす年の性能 評価方法に準じて, 重心位置, 走行速度, 登坂 能力, 段差乗り越え高さ, 連続走行時間を調べ た。重心位置は車いす自体と砂袋のテストダミ 一を載せた状態それぞれで，水平面内位置はフ オースプレートを用い, 鉛直方向の位置は釣り 下げ法によった。走行速度は車いす台上試験機 を使用し, 速度設定後 10 秒から 30 秒の両後輪の 平均速度として求めた。登坂試験は 0 度から 10 度の範囲で傾斜を自由に設定できるスロープを， 0.5 度刻みで傾斜を変えながら, その都度, 体重 $75 \mathrm{~kg}$ の人乗ってもらい補助動力のみで上るよ う指示した。またC7レベルの先髄損傷者, 1 名 に同じく，補助動力を使用して登坂を試みても らった。段差乗り越えについては, 高さの可変

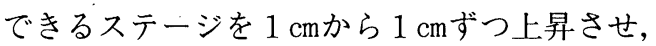
前方 $30 \mathrm{~cm}$ の位置から前輪で接近し乗り越えを行 つた。連続走行時間は平地アスファルト上を連 続で走行可能な時間として求めた。

\section{2 性能試験結果}

重心位置は車いすだけの状態で車いす後輪軸 位置から水平面前方に $154 \mathrm{~mm}$, 垂直方向で上方に $40 \mathrm{~mm}$ となっていた。またISO規格のテストダミ - ${ }^{2)}(75 \mathrm{~kg})$ を載せた状態では同様に前方に204 $\mathrm{mm}$ ，上方に $260 \mathrm{~mm}$ となっていた。

最大登坂角度は, 補助動力だけで 5 度以上で あった。試乗したC7レベルの脊髄損傷者（男性 38歳）の場合, 約 8 度のスロープを上ることも 可能であった。

モー夕駆動電圧12，18，24Vにおける走行速 度, 段差乗り越え, 連続走行時間の結果に関し ては表 2 に示す。

Table.2 Performance test results

\begin{tabular}{ll}
\hline Speed & Low : $2.4 \mathrm{~km} / \mathrm{h}(12 \mathrm{~V})$ \\
& $\begin{array}{l}\text { Middle : } 3.9 \mathrm{~km} / \mathrm{h}(18 \mathrm{~V}) \\
\text { High : } 5.2 \mathrm{~km} / \mathrm{h}(24 \mathrm{~V})\end{array}$ \\
Max. Slope Angle & $\begin{array}{l}>4.8 \mathrm{deg}(70 \mathrm{~kg} \text { male) } \\
8 \mathrm{deg} \text { with power assist } \\
\text { (C7 male) }\end{array}$ \\
Bump height & $30 \mathrm{~mm}$ (forward approach) \\
Continuous run time & ca. 1 hour on flat floor \\
\hline
\end{tabular}

\section{3 速度制御の実験とその結果}

アスファルト路面での平地走行, 屋外12分の 1のスロープの上り下りを低速（設定速度 $2 \mathrm{~km}$ /h）で行わせて，速度制御の効果を記録し検討 した ${ }^{11)}$ 。

図 5 は平地走行時の速度の時間变化を示した ものである。指令速度に対して行き過き，戻り すぎが見られる。プログラム上の制御間隔が 1 回転毎で長すぎると考えられる。

図 6 は同様に12分の 1 のスロープを下る際の ものである。全く制御しない場合の罒 7 で $7 \mathrm{~km}$ /hまで加速するのと比較し, ブレーキが掛けら れ設定速度に近づいているのがわかる。

図 8 は同様に12分の 1 のスロープを上る際の ものである。時間 0 の近くで速度がバ夕つくの は駆動力が上昇していくが, 車いすが平地から 上りスロープに差し掛かって負荷が急に増加す るためと考えられる。 


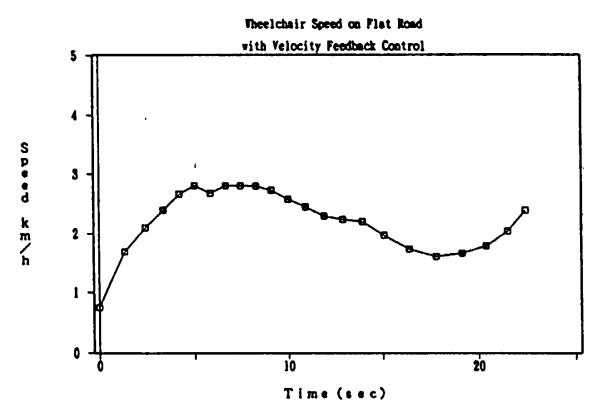

Fig. 5 Speed as function of PWM duty ratio, with $65 \mathrm{~kg}$ man, on flat floor, linear motion (reference: $2 \mathrm{~km} / \mathrm{h}$ )

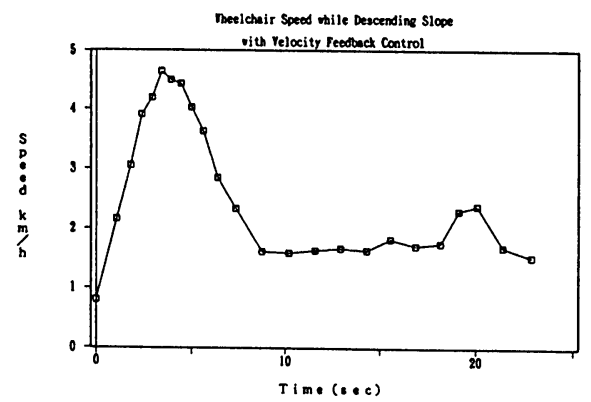

Fig. 6 Speed as function of PWM duty ratio, with $65 \mathrm{~kg}$ man, on downslope, liner motion (reference: $2 \mathrm{~km} / \mathrm{h}$ )

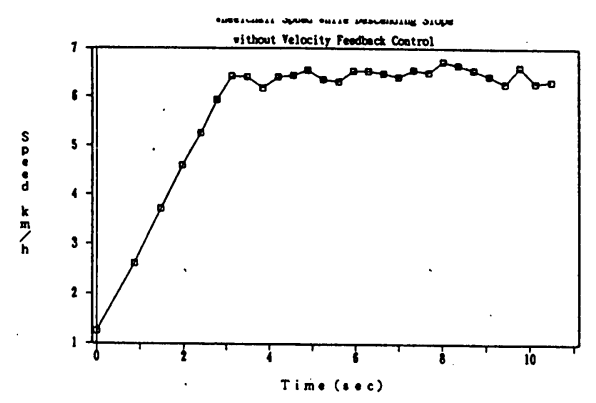

Fig.7 Speed as function of PWM duty ratio, with $65 \mathrm{~kg}$ man, on downslope, linear motion (reference: $2 \mathrm{~km} / \mathrm{h}$, without feedback)

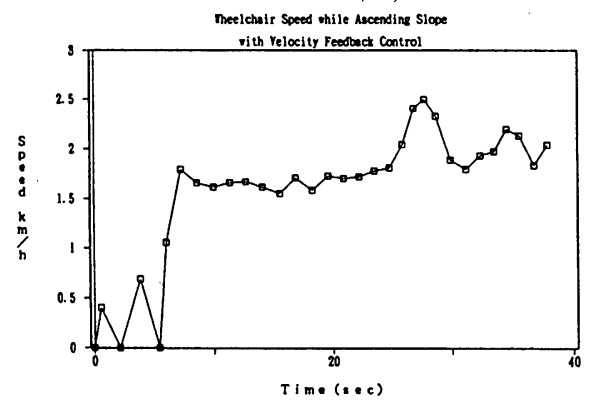

Fig. 8 Speed as function of PWM duty ratio, with $65 \mathrm{~kg}$ man, on upslope, linear motion (reference: $2 \mathrm{~km} / \mathrm{h}$ )

\section{4 フィールドテスト 910)}

先のC 7 レベルの方に屋内(布地カーペット, $\mathrm{P}$ タイル), 屋外(夕イル, アスファルト)で平地 直進走行, 平地回転運動を行ってもらい, 運転 操作, 乗り心地に関する評価をしていただいた。 また，神奈川県障害者能力開発校の車いすを 利用している訓練生計10名 (内, 女性1名)には図 9に示すようなテストコースを, 試作した車い

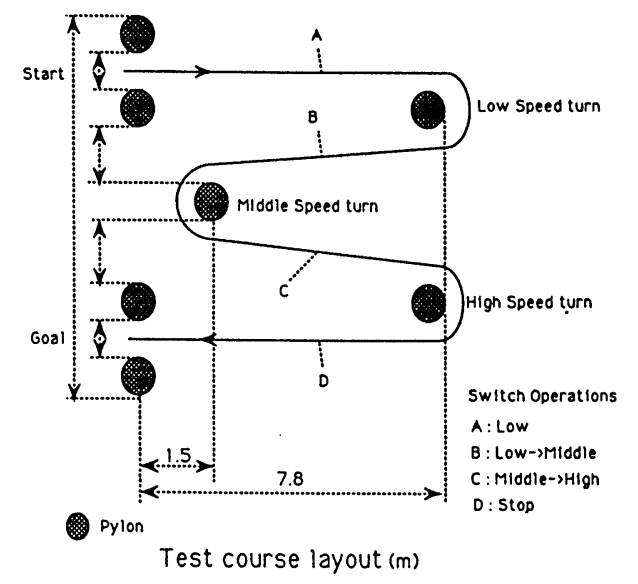

Fig. 9 Field test course layout (m)

Table 3 Profile of people for trial ride of wheelchair with assistive power unit

\begin{tabular}{|l|l|l|}
\hline \multirow{4}{*}{ Age } & $10-19$ & 3 \\
\cline { 2 - 3 } & $20-29$ & 5 \\
\cline { 2 - 3 } & $30-39$ & 1 \\
\cline { 2 - 3 } & $40-49$ & 1 \\
\hline \multirow{4}{*}{ Weight $(\mathrm{cm})$} & $130-140$ & 2 \\
\cline { 2 - 3 } & $150-160$ & 1 \\
\cline { 2 - 3 } & $160-170$ & 6 \\
\cline { 2 - 3 } & $170-180$ & 1 \\
\hline \multirow{4}{*}{$\begin{array}{l}\text { Type of } \\
\text { impairment }(\mathrm{kg})\end{array}$} & $30-40$ & 1 \\
\cline { 2 - 3 } & $40-50$ & 3 \\
\cline { 2 - 3 } & $50-60$ & 4 \\
\cline { 2 - 3 } & $60-70$ & 2 \\
\hline \multirow{5}{*}{$\begin{array}{l}\text { Experience of } \\
\text { wheelchair }\end{array}$} & Lower limb dysfunction & 2 \\
\cline { 2 - 3 } use (year) & Lumbar or thoratic spinal cord injury & 6 \\
\cline { 2 - 3 } & Cerebral palsy & 1 \\
\cline { 2 - 3 } & No answer & 1 \\
\cline { 2 - 3 } & $2-1$ & 1 \\
\cline { 2 - 3 } & $3-4$ & 2 \\
\cline { 2 - 3 } & $7-8$ & 2 \\
\cline { 2 - 3 } & $9-10$ & (Total 10$)$ \\
\cline { 2 - 3 } & $12-13$ & \\
\hline
\end{tabular}


すで速度を変えて走行してもらい，アンケート に答えてもらった。表 3 に訓練生の年齢, 身長, 体重, 障害種別, 車いすの使用年数を示す。

尚，以上のフィールドテストにおいては，制 御回路では電圧切り替え回路を用いた。

\section{5 フィールドテスト結果}

C 7 レベルの方から「手動としてはやや重い。 しかしスロープの上り下り旋回が楽である」と いう感想をいただいた。また平地走行時の操舵 は視認できるほどの蛇行はなく，この方に関し て問題は無かった。旋回時など曲がる方向のブ レーキを引くことで敏速に方向転換でき，手を 握ることができないC 7 レベルの人（図10）で もわずかな操作力で旋回できることもわかった。

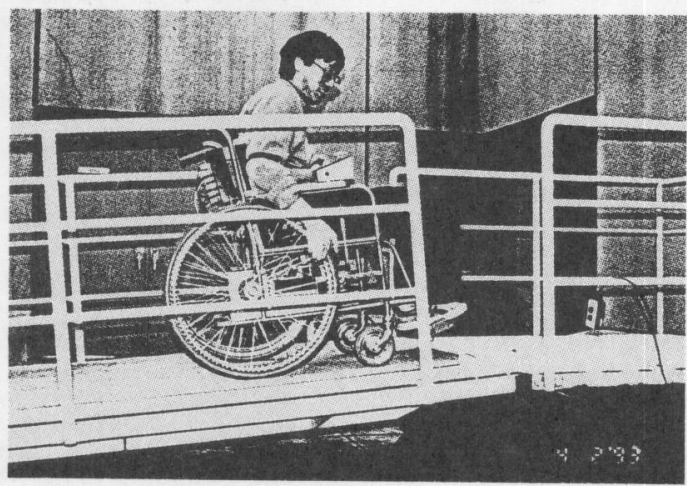

Fig.10 Test run by a C7 spinal cord injury male

Table 4 Answers to questionnaire (in 5 ranks)

Q1. Collaboration with power assist while driving the wheelchair

\begin{tabular}{|c|l||c|c|c|c|c|}
\hline \multirow{2}{*}{ speed } & \multicolumn{1}{|l||}{ Motion } & \multicolumn{3}{|c|}{ difficult } & $\langle----->$ & easy \\
\hline \hline \multirow{2}{*}{ Low } & Straight & & 1 & 1 & 1 & 7 \\
\cline { 2 - 7 } & Turning & & & 1 & 3 & 6 \\
\hline \multirow{2}{*}{ Middle } & Straight & 1 & & 2 & 1 & 6 \\
\cline { 2 - 7 } & Turning & 1 & 1 & 2 & 3 & 3 \\
\hline \multirow{2}{*}{ High } & Straight & 2 & 1 & 3 & & 4 \\
\cline { 2 - 7 } & Turning & 2 & 3 & 1 & 1 & 2 \\
\hline \multirow{2}{*}{ (Total 10) }
\end{tabular}

Q2. Switch box operation while driving the wheelchair

\begin{tabular}{|c|c|c|c|c|}
\hline speed & difficult $<$ & $\cdots$ & $>e$ & \\
\hline Low & & 2 & 1 & 7 \\
\hline Middle & & 2 & 1 & 7 \\
\hline High & & 2 & 2 & 6 \\
\hline
\end{tabular}

スイッチの操作に関しては，当初作成したスイ ッチボックスでは手指の細かな動作が困難なた め，キートップが小さく操作しづらいことがわ かり，キートップの大きなものにし，数も 4 つ から 3 つに減らした。

他方，障害者能力開発校の 10 名の走行テスト の結果は, 試乗者が比較的若いこともあって

(平均 25.5 歳) 操作を覚えるのは 10 分程度, 旋 回時に小さく回れない人が数名いたが，他の操 作で特に問題はなかった。アンケートの質問と 結果を表 4 に示す。試乗者自身も操作が全般的 に容易であるという感想が多い。しかし，高速 走行時の操作において特に方向転換において補 助動力と協調した車いすの駆動が難しいと感じ た人が半数を数えた。

\section{5.考察}

5.1 性能試験

(1)段差の乗り越えの高さ

JIS試験に準じると補助動力を使用しても変わ らなかった。これは前輪キャス夕の径が手動の 車いすのもので大きさが $15 \mathrm{~cm}$ とっていること による。したがってこの段差に関しての補助に よる乗り越えは手動の車いすの前輪を利用する 限り難しいと考えられる。電動車いすのように 前輪を用いた段差乗り越えではなく，後輪によ るアプローチと前輪キャス夕上げの動作といっ た手動車いすとしての乗り越え方が考えられる。

しかしながら，試作した車いすのフレームと して活用した片麻痺者用の車いすは，一般的な 手動車いすのフレームの後ろにベアリングを溶 接して軸を取り付けるため, $3 \mathrm{~cm}$ 程度軸が後方 へ移動している。このことが車いす重量の増加 よりも影響が大きく，キャス夕上げと段差乗り 越えを困難にしている。

実際，重心位置のデー夕を見れば前進時のホ イールベースが約 $41 \mathrm{~cm}$ に対して，テストダミー 搭載時には後輪軸取付位置から前方へ $204 \mathrm{~mm}$ で, 前輪と後輪での加重分担比がほぼ $50 \%$ ずつとな つており，手動車いすで一般的な $40 ： 60$ の比か ら前輪の方へ負担が増加していることを裹付け ている。 
(2)平地直進走行

屋内 $\mathrm{P}$ タイル, 屋外タイル, アスファルト路 面など走行を行い, 補助動力のみにより現状の 電動車いすのように走行することが可能であっ た。しかし，前輪が一般の手動車いすと同様自 在輪を用いているため, 使用者による操舵を必 要とする。操舵するだけの残存保有機能を保持 していない場合には使用が困難になると考えら れた。

(3)旋回動作

差動歯車機構により曲がる方向のブレーキを 強く掛けると，その分の駆動力が外側にあたる 後輪の駆動力に回り, 旋回がスムーズに行える ことがわかった。例えばJIS電動車いすの回転性 能（屋外用）の所に規定されるように $1.2 \mathrm{~m}$ 幅の 直角路を曲がることができる。さらにブレーキ の引き方を工夫すれば回転半径も調節できる。 また手動に切り替えれば一般の電動車いすにで きない小回りが可能となる。ただし，レバーブ レーキはタイヤを削ることになりタイヤの摩耗 を著しく早めるので, ドラム式のキャリパーブ レーキ等に変更するのが良いと考える。

(4)スロープの上り下り

上りの際には速度が遅くなるため操舵が重く なる。狭い通路では，壁を手で押しながら操舵 するなどの工夫が必要とされる。また上りから 平坦路に移る場合, 下りから平坦路に移る場合 など，駆動モー夕に対する負荷が大きく変化す るが，速度フィードバックを掛ける制御により 設定速度に対しての変動を抑えることができた。 (5)車いすの補助動力による駆動と使用者の駆動 の協調

現在は，使用者が車いすの回転に合わせる， 合わせられない時は速度を変える，といった方 法を取っているが，これは使用者に対して操作 をわずらわしくしている。例えば車いすを駆動 するピッチは一定にしてそのときの補助トルク を必要トルクに比例して出力すれば, 使い心地 が良好となり疲労感を低減することができるの ではないかと考えられる。

\section{2 フィールドテスト}

今回試行したフィールドテストで試乗してい ただいた人は, 処方の際, 電動車いすか手動車 いすか判断の難しいC 5，C 6の人ではなく, ふだん手動車いすを使用している人であったが, これらの人に対してもスロープの上り下りや回 転動作において補助動力を有効に活用できるこ とがアンケートの中から明らかになった。自立 を支援しようと想定した使用者の下肢障害のC 5，6レベルの人に対して，この車いすが使え るかどうかは, その操舵能力の有無に関わると 考えられる。

一方, 一般の手動車いすに比べ重くなったこ と, 駆動軸の位置が後退したこと, 特に高速駆 動時に駆動の協調が難しいこと, 登坂時に操舵 が難しいことがフィールドテストからも確認さ れた。

操作スイッチに関してはC 7 レベルの被験者 の要望でキートップの大きなもの（ え, またスイッチの数もモータのスイッチ, 正 転逆転スイッチ, クラッチのスイッチ, 低・中 ・高の速度設定と 4 個あったものを緊急停止, 速度設定スイッチ 2 つの計 3 個に減らした。し かし，大きなスイッチはトランスファーの際に 邪魔で, 特に手指の動作に問題のない使用者か ら不評であった。操作スイッチに関しては操作 者の保有機能に合わせたものを製作する必要が ある。

\section{3 構造, 制御に関して}

段差乗り越えなど手動車いすとしての使用法 を考虑する場合, 補助動力機構を取り付ける車 いすとしては, 後輪軸の位置が背もたれ部の延 長上より前にあるものがよいと考えられる。例 えば, 各部の調節が可能な市販のモジュール型 車いすを用いれば，最大で $5 \mathrm{~cm}$ 幅， $5 \mathrm{~mm}$ 間隔で 軸前後方向位置を調節可能で, しかも軸取り付 けが可能である。

補助動力付き車いすの構造全般に関しては, スイッチボックスが大きすぎて移乗（トランス ファー）の邪魔になること，駆動軸がベアリン グの分だけ後退して駆動しにくいこと, ギヤ部 
の騒音が大きいことなどの問題があげられる。 運搬を考えると駆動機構の脱着, 折り畳みも使 用者の中で要望が強い。また使用者の駆動がな くてもスロープ等上れるようにとモー夕に $120 \mathrm{~W}$ のものを使用したが, 補助が少なくてもよい人 にはさらに補助力を適正化することによって補 助動力機構を小型化，軽量化，さらには脱着機 構がより簡単になると考えられる。

制御に関しては，PWM制御により滑らかな 速度制御を実現できた。さらに，回転角度セン サを使用し，速度フィードバックを行うことに より，スロープの上り下りに負荷の変動による 速度変化を抑えることができた。下り坂の際の ブレーキのきき具合の立ち上がりが遅いこと， 平地走行時の設定速度への行きすぎ，戻りすぎ が大きいが，ソフトウェアの改良や回転角度セ ンサ数の増加により解決されると考えられる。 負荷がかかったときに補助動力量をその負荷に 応じて増すといった，トルクフィードバック ${ }^{5) 6}$ については今後の課題である。

\section{6.結 論}

電動車いすを常に使用することにすると, 残 存保有機能の低下が愁念される人を対象とし, その維持活用を図る目的で補助動力付き手動車 いすを試作した。健常者, 車いす利用者による 試乗, 改良を行った結果, 次の結果が得られた。

(1)差動歯車機構を用いたことによりモー夕を 1 つにでき, 軽量でかつ旋回が容易となった ${ }^{12)}$ 。

(2)体重 $75 \mathrm{~kg}$ の.人載せ,建築物に推奖される, 傾斜12分の 1 のスロープの上り下りが補助動力 だけで可能となった。

(3)マイクロコンピュー夕，回転角度センサを 使用した制御回路により速度フィードバック制 御が可能となり, 負荷の変動に対する速度変動 を抑えることが可能となった。

残存保有機能の維持活用を図るという目的は, リハビリテーションの現在の流れに適合してお ク, 症状の固定した人ばかりでなく, リハビリ テーションの過程でも補助動力付き車いすは使
用可能である。

今後は, 車いす使用者からの感想の中で希望 が多かった, 運搬のための機構脱着化, 使用者 の操作機能に適したスイッチ, 速度フィードバ ックソフトウェアの改良, また使用者の駆動力 に合わせた補助動力のトルク制御につき検討し ていく予定である。

\section{謝辞}

本研究において中心的に研究を行った平成 4 年度本校, 研究課程生の内山拓哉君, フィール ドテストにおいて多大なご協力をいただいた横 浜リハビリテーションセンターの松野さんをは じめとする皆さん、神奈川県障害者能力開発校 の皆さんに深く感謝いたします。

\section{参考文献}

1) 厚生省社会局：身体障害者実態調查，1991

2 ）大川嗣雄, 伊藤利之, 田中 理, 飯島浩 : 車いす, 医学書院, 1987

3 ）日本工業標準調査会：JIS電動車いす JIS T 9203, 1986

4 ）日本工業標準調査会：JIS手動車いす JIS T 9201, 1986

5 ) 片山滋友, 関根正次 : 手動式電動車椅子の 研究, バイオメカニズム学術講演会予稿集, 91-92, 1985

6 ) G.B. Cremers: Hybrid-powered wheelchair : A combination of arm force and electrical power for propelling a wheelchair, Journal of Medicine and Engineering Technology, Vol.13, N01 /2, 142-148, 1989

7 ) 内山拓哉, 舟久保昭夫, 垣本 映, 鈴木重 信, 磯村 恒, 関口行雄: 補助動力を用い た手動車いすの開発, 1993年度精密工学会 春季大会学術講演論文集, 813-814, 1992

8 ) 内山拓哉, 垣本 映, 鈴木重信, 磯村 恒, 関口行雄: 補助動力を用した手動車椅子の 開発, 第 8 回エルエスティ学会大会講演予 稿集, 43, 1992

9 ) 内山拓哉, 垣本 映, 鈴木重信, 関口行雄 
: 補助動力付き手動車いすの開発, 第 2 回 人と福祉を支える技術フォーラム 93 論文集, S04, 1993

10）内山拓哉, 垣本 映, 舟久保昭夫, 鈴木重 信, 関口行雄：補助動力付き手動車いすの 開発, 第 8 回リ八工学カンファレンス講演 論文集，561，1993
11）垣本 映，舟久保昭夫，鈴木重信，関口行 雄：補助動力を用いた手動車いすの開発 (第 2 報)，1993年度精密工学会秋季大会学 術講演論文集，243-244，1993

12）日本工業新聞：手動・電動折京の車いす, 93年 4 月 7 日号 